As noções de natureza e homem em Gilles Deleuze e suas relações

\title{
As noções de natureza e homem em Gilles Deleuze e suas relações ${ }^{1}$
}

\section{The notions of nature and man in Gilles Deleuze and their relations}

\section{ESTER MARIA DREHER HEUSER²}

Resumo: Nesse artigo, traço uma cartografia quanto à maneira pela qual Deleuze desterritorializa o debate em torno da relação homem-natureza para além da clássica lógica binária sujeito/objeto. Busco ainda explorar que esse procedimento se opera pela aproximação das artes a fim de recolher nessas, aquilo que, em última análise, é capaz de "violentar" o pensamento como fluxo, dobra, afeto, intensidade e experimento.

Palavras-chave: Deleuze. Homem. Natureza. Arte. Experimento.

Abstract: In this paper, trace a cartography as to how Deleuze deterritorialized the debate on human-nature relationship beyond the classical binary logic subject/object. Seeking still explore this procedure operates by aligning the arts in order to collect these, what, ultimately, is capable of "ravish" as the thought flux, fold, affection, intensity and experiment.

Keywords: Deleuze. Man. Nature. Art. Experiment.

Considerando que Gilles Deleuze (1925-1995) é filósofo contemporâneo e tem, como nós, mais de dois mil anos de história do pensamento filosófico pairando sobre sua cabeça, cabe, inicialmente, apresentar qual sua relação com essa história e quem são seus aliados para pensar as noções de natureza, homem e suas relações. Deleuze é um crítico mordaz à história da filosofia, especialmente aos usos que costumeiramente se faz dela. Como estudante de graduação de filosofia, Deleuze teve uma experiência

1 Texto preparado para o $3^{\text {o }}$ Encontro do Ciclo de Palestras e Debates 2012, realizado dia 15 de agosto, no contexto do planejamento de atividades do Grupo PET.

2 Doutora em Educação e Professora dos Cursos de Graduação e Mestrado em Filosofia da Unioeste, Toledo, Paraná - Brasil. Endereço eletrônico: esterheu@ hotmail.com 
negativa com ela, diz ter feito parte de uma geração que foi quase assassinada pela história da filosofia, sobre isso ele conta:

Era história demais quando chegávamos lá, método demais, imitação, comentário e interpretação, a não ser por Sartre [...] Felizmente, havia Sartre. Sartre era nosso Fora, era realmente a corrente de ar fresco [...]. E Sartre nunca deixou de ser isso, não um modelo, um método ou um exemplo, mas um pouco de ar puro, uma corrente de ar [...]; um intelectual que mudava singularmente a situação do intelectual [...]. A história da filosofia sempre foi o agente de poder na filosofia, e mesmo no pensamento. Ela desempenhou o papel de repressor: como você quer pensar sem ter lido Platão, Descartes, Kant e Heidegger, e o livro de fulano e sicrano sobre eles? Uma formidável escola de intimidação que fabrica especialistas do pensamento [...]. Uma imagem do pensamento, chamada filosofia constituiu-se historicamente e impede perfeitamente as pessoas de pensarem (DELEUZE, 1998, p. 20-21).

Coma negatividade da experiência, Deleuzepoderia ter aberto mão da história da filosofia, mas isto não ocorreu. Tanto em suas aulas, como em seus livros fez outro uso dela: um uso funcionalista. Tratou de um autor, de uma filosofia mostrando como ela funciona, com quais engrenagens. Ao invés de questionar: "o que isso quer dizer?”, perguntou: “como isso funciona?”. E nos sugere que façamos o mesmo, perguntando: como isso funciona para você? Por fim, recomenda: se não funciona abandone o livro; troque-o por outro (DELEUZE, 1992, p. 16) - por algum que faça com que algo em você se mexa. Ou seja, se nada se passa entre você e o livro, desista dele, tome um que faça passar intensidades, fluxos, processos, coisas que não querem dizer nada, que não têm um significado escondido a ser encontrado, uma verdade a ser desvendada; um livro com ideias que tenham ligação com o Fora, com o exterior da filosofia e do pensamento, com aquilo que impulsiona, provoca, violenta o pensamento, que tira-o do mero exercício de reconhecimento e abre-o para a possibilidade da criação. Foi com essa perspectiva que selecionou filósofos da tradição, tais como Hume, Bergson, Spinoza e Nietzsche, orientados pela cultura da alegria, pela exterioridade das forças e das relações. Com esses filósofos, inventou seus 
próprios métodos, novas regras e um novo tom para a filosofia: por meio da técnica da colagem, utilizada por artistas do século XX, desterritorializada para a filosofia ${ }^{3}$ compôs seus próprios conceitos, isto a partir de elementos diversos de filosofias variadas, bem como a partir da não-filosofia, da literatura, da pintura, do cinema e das ciências. Assim, considero que Deleuze fez da filosofia uma arte do encontro e da composição, na medida em que criou aquilo que nomeou de empirismo superior, ou empirismo transcendental.

Não o empirismo comumente definido pela história da filosofia em oposição ao racionalismo como uma crítica ao inatismo, uma teoria segundo a qual o inteligível, o conhecimento, tudo o que diz respeito ao entendimento vem dos sentidos, começa e deriva da experiência; não um empirismo preocupado com o conhecimento que pertence a um sujeito e remete a um objeto. Ao invés disso, trata-se de um empirismo que se opõe a tudo o que compõe o mundo organizado e justificado pela lógica do sujeito e do objeto, dos estados de coisas, do mundo da matéria formada; é

3 Em sua filosofia das relações, Deleuze retira do território das artes a técnica da colagem, utilizada especialmente pelos dadaístas e a reterritorializa na filosofia: "A colagem é conhecida como um procedimento artístico que consiste em unir pedaços de papel liso, estampado, pintado ou impresso (jornais, embalagens), cartão, tecido ou pequenos objetos sobre um suporte geralmente plano. Começou a ser praticada por diversos grupos de artistas plásticos a partir dos primeiros anos do século XX, mas técnicas análogas foram usadas por músicos e poetas" (In: http://www.pucsp.br/ponto-e-virgula/n1/artigos/o2-DodiPassetti. htm). Analogia que Deleuze fez à sua ideia de filosofia e de um livro filosófico por vir: "Aproxima-se o tempo em que já não será possível escrever um livro de Filosofia como há muito tempo se faz: 'Ah! O velho estilo...' A pesquisa de novos meios de expressão filosófica foi inaugurada por Nietzsche e deve prosseguir, hoje, relacionada à renovação de outras artes, como, por exemplo, o teatro ou o cinema. A este respeito, podemos, desde já, levantar a questão da utilização da História da Filosofia. Parece-nos que a História da Filosofia deve desempenhar um papel bastante análogo ao da colagem numa pintura. A História da Filosofia é a reprodução da própria Filosofia. Seria preciso que a resenha em História da Filosofia atuasse como um verdadeiro duplo e que comportasse a modificação máxima própria do duplo (imagina-se um Hegel filosoficamente barbudo, um Marx filosoficamente glabro, do mesmo modo que uma Gioconda bigoduda). Seria preciso expor um livro real da Filosofia passada como se se tratasse de um livro imaginário e fingido" (DELEUZE, 1988, p. 19). Trata-se, em nossa interpretação a respeito da proposta de Deleuze, de uma dessacralização da história da filosofia, tal como Duchamp dessacralizou a arte quando em 1919 expôs uma reprodução da Gioconda de Da Vinci desenhando bigodes nela. Dessacralização para a abertura de novas possibilidades para o pensamento conceitual, para que passe ar puro na própria história da filosofia. 
antes, um empirismo a-subjetivo e a-objetivo, explicado por uma “estranha 'razão' o múltiplo e o caos da diferença [...] diferença que está por trás de toda coisa, mas nada há atrás da diferença”, por isso, um empirismo transcendental (DELEUZE, 1988, p. 107; 2002, p. 10).

Entendo que desde o primeiro livro, Empirismo $e$ subjetividade (1958/2001), quando ainda era um jovem professor, Deleuze, ao apresentar a filosofia de Hume, estava compondo o seu próprio empirismo e a sua teoria das faculdades - peça chave para a constituição de tal empirismo (HEUSER, 2010) para tanto, foi preciso engendrar a gênese do pensar, isto é, fazer a descrição genética das condições de efetividade da experiência, sempre frente à violência que lhe é própria, edificando uma teoria diferencial das faculdades. Nesta primeira obra, Deleuze assegura que o fundo único do empirismo, seu ponto de partida, é a afirmação da imanência, o que implica não pôr em dúvida a existência do mundo, do dado, da experiência. Aliás, muito tempo depois, em 1990, Deleuze, em uma entrevista afirmará: "Acreditar no mundo é o que mais nos falta; nós perdemos completamente o mundo, nos desapossaram dele. Acreditar no mundo significa principalmente suscitar acontecimentos, mesmo pequenos, que escapem ao controle..." (DELEUZE, 1992, p. 218). Para Deleuze e, para o empirismo, o problema de uma origem, de uma causa da natureza e do espírito também não se coloca. Ou seja, nas linhas de Hume, há o mundo, o dado, sucessão movimentada de percepções distintas - fluxo do sensível, conjunto de percepções e, nele, o espírito, puro delírio, coleção de ideias ligadas ao acaso ${ }^{4}$, imaginação fantasista e delirante, absolutamente embaralhada e sem determinação: movimento de ideias inconstantes que percorre o universo livremente e cria cavalos alados, dragões de fogo e gigantes monstruosos (HUME, 2001, p. 34). Por meio desse mundo selvagem de constante mudança, movimento sem identidade nem lei - anarquia coroada -, que pode ser chamado simplesmente de experiência, a questão do empirismo que afirma o dado tal como o conjunto do que aparece é a da subjetividade. $\mathrm{Ou}$ melhor: o problema da constituição do sujeito a partir do dado, os processos de subjetivação, ou, como Deleuze preferirá mais tarde:

4 Acaso enquanto negação de uma causa que, por sua vez, traça o caminho para o pensamento e força-o a considerar objetos determinados em relações determinadas. Tudo o que o acaso faz é destruir tal determinação do pensamento, deixando a mente em seu estado original de indiferença (HUME, 2001, p. 158). 
As noções de natureza e homem em Gilles Deleuze e suas relações

produção de novos tipos de acontecimentos (DELEUZE, 1992, p. 218). Em tal produção, vemos a questão "o que significa pensar?" sempre presente de modo que compreendo que é esse o problema orientador da filosofia de Deleuze.

Ao encontrar-se com Hume, Deleuze mostra uma das originalidades do empirista inglês e que será adotada pelo francês, qual seja: "as relações são exteriores aos seus termos" (DELEUZE, 1995, p. 210; grifos do autor). Uma vez que há, exclusivamente, ideias nas impressões sensíveis, as relações ${ }^{5}$ entre elas são, necessariamente, exteriores e heterogêneas a seus termos, impressões ou ideias. Deleuze afirma que Hume foi o primeiro a desdobrar o mundo empirista em toda a sua extensão e elevar o empirismo a uma potência superior. Inaugurando o ponto de vista transcendental, tornou manifesta a exterioridade do mundo, um mundo ilógico

[...] em que o próprio pensamento está numa relação fundamental com o Exterior [o Fora], mundo em que há termos que são verdadeiros átomos, e relações que são verdadeiras passagens externas - mundo onde a conjunção 'e' destrona a interioridade do verbo 'é' (DELEUZE, 1995, p. 211).

É em decorrência da exterioridade das relações ou das conjunções, que se pode afirmar que o espírito devém uma natureza humana, que o sujeito se constitui no dado e o ultrapassa em um mundo "conjuntivo de átomos e relações" (DELEUZE, 1995, p. 211). Ou seja, éà medida que variam as relações entre as ideias, enquanto faz diferentes conexões entre os termos, na medida em que cria, inventa relações, experiencia ilimitadas combinações, faz rizoma, que o espírito devém homem e se constitui enquanto sujeito. $\mathrm{O}$ privilégio da exterioridade e a autonomia das relações entre termos e ideias é a base para o construcionismo filosófico de Deleuze, para a invenção de inauditas combinações, para a arte do encontro e da composição em um "mundo de Arlequim, com toda a variedade de matizes e de fragmentos não totalizáveis onde se comunica por

5 Relação "é o que nos faz passar de uma impressão ou de uma ideia dadas à ideia de alguma coisa que não é atualmente dada. Por exemplo, penso em algo de 'semelhante'... Ao ver o retrato de Pedro, penso em Pedro, que não está aí" (DELEUZE, 1995, p. 210). 
meio de relações exteriroes" (DELEUZE, 1995, p. 211). Daí sobrevém também a concepção de filosofia como agenciamento, no sentido de uma composição de elementos distintos, ideias, relações e circunstâncias capaz de criar conceitos que possam mudar nossa relação com o mundo. A ideia de filosofia como agenciamento que Deleuze intensificará em seu encontro com Guattari - põe em relação todas as formas de conexão, inclusive as não-humanas:

[...] todas as combinações são possíveis entre máquinas técnicas, animais e humanos. São sempre processos de subjetivação, de individuação que estão no horizonte. Tal objetivo pressupõe não somente desvios, mas também reconecta o homem com a natureza, com a physis. Na verdade, não há mais distinção pertinente, no nível das ligações de agenciamento, entre natureza e artifício (DOSSE, 2010, p. 211).

Para abordar o problema que nos reúne hoje, aqui, e que há muito vem sendo pensado pelos componentes do PET, decidi chamar, além de Hume, três outras figuras caríssimas a Deleuze para ver se elas podem funcionar na composição da tematização, numa perspectiva deleuziana, a respeito das noções de natureza/ homem e suas relações. [Ainda que tal chamada torne essa abordagem difusa, acredito que a singularidade aberta e rizomática da filosofia de Deleuze possa mesmo abrir para uma diversidade de perspectivas talvez ainda impensadas nesse grupo de jovens pesquisadores]. Trata-se de três figuras solitárias. Solitárias porque são sem lugar, porque a elas era impossível integrar-se a qualquer meio, uma vez que eram átopos. Ocupavam, propriamente, a condição do filósofo, pois, para Deleuze: "O filósofo pode residir em diversos Estados, habitar diferentes meios, mas à maneira de um eremita, de uma sombra, viandante, inquilino de apartamentos mobiliados" (DELEUZE, 2002, p. 10). De acordo com Deleuze, o único espaço para o filósofo é o da resistência, resistência ao seu tempo "a favor, espero, de um tempo por vir". (DELEUZE, 2002, p. $10)$.

A primeira dessas figuras é aquela que Deleuze chama de "cristo dos filósofos" (DELEUZE e GUATTARI, 1992, p. 79), o artesão, ou operário da filosofia: Spinoza. No prefácio à terceira 
parte de sua obra Ética, ele escreve:

Os que escreveram sobre os afetos e o modo de vida dos homens parecem [...] conceber o homem na natureza como um império num império. Pois acreditam que, em vez de seguir a ordem da natureza, o homem a perturba, que ele tem uma potência absoluta sobre suas próprias ações, e que não é determinado por nada mais além de si próprio. Além disso, atribuem a causa da impotência e da inconstância não à potência comum da natureza, mas a não sei qual defeito da natureza humana, a qual, assim, deploram, ridicularizam, desprezam ou, mais frequentemente, abominam [...]. Mas ninguém, que eu saiba, determinou a natureza e a força dos afetos nem, por outro lado, que poder tem a mente para regulá-los [...] eis aqui o meu raciocínio. Nada se produz na natureza que se possa atribuir a um defeito próprio dela, pois a natureza é sempre a mesma, e uma só e a mesma em toda parte, sua virtude e potência de agir. Isto é, as leis e as regras da natureza, de acordo com as quais todas as coisas se produzem e mudam de forma, são sempre as mesmas em toda parte [...]. Tratarei, assim, da natureza e da virtude dos afetos, bem como da potência da mente sobre eles, [...] considerarei as ações e os apetites humanos exatamente como se fossem uma questão de linhas, de superfícies ou de corpos (SPINOZA, 2007, p. 161-162).

Conservemos, por ora, para tematizar nosso problema, a contrariedade de Spinoza à ideia de que o homem é um império à parte dentro do império da natureza e sua proposta de que o homem e todas as coisas são produção da natureza.

A segunda figura é Bergson, que, em As duas fontes da moral e da religião (1978), afirma o caráter utilitarista da natureza e mostra o demorado trabalho que ela teve para resolver problemas a fim de atender às suas próprias exigências vitais. Enquanto a natureza deu instintos aos animais, aos homens deu-lhes inteligência ${ }^{6}$, cuja

6 Em Instintos e instituições, texto de Deleuze ordenado por ele próprio no bloco de textos "De Hume a Bergson", se afirma que quanto mais imperfeito for o instinto na espécie, mais submetido estará à variação, à indecisão, a circunstâncias exteriores e, assim, ele dará mais lugar à inteligência. No caso do homem, que tem instintos fracos, ou não os tem, a fim de satisfazer suas tendências e necessidades, 
função original é:

[...] resolver problemas análogos àqueles que o instinto soluciona, por método muito diferente, é certo, que garante o progresso e que não se pode executar sem uma independência teoricamente completa em relação à natureza. Mas essa independência é limitada, de fato: ela se detém no exato momento em que a natureza vá contra seu alvo, frustrando um interesse vital. A inteligência é, pois, necessariamente vigiada pelo instinto, ou antes, pela vida, origem comum do instinto e da inteligência (BERGSON, 1978, p. 133).

Bergson reconhece que, no entanto, a evolução criadora da natureza - a própria Duração, o Movimento, o Impulso vital aconteceu de modo descontínuo; se deu por saltos e, a cada parada, produziu uma "combinação perfeita em seu gênero comparável às figuras que se sucedem quando se gira um caleidoscópio" (BERGSON, 1978, p. 105). O mesmo é dito em outras palavras por Deleuze, em Bergsonismo (DELEUZE, 1999, p. 84): "toda espécie é, portanto, uma parada de movimento [...] funciona como uma solução vital tão perfeita quanto pode sê-lo em variados graus";

a inteligência cria instituições (por exemplo, para satisfazer as necessidades sexuais e a procriação da espécie, cria-se o casamento), desse modo, na natureza, há duas formas organizadas de uma satisfação possível num meio dado: o instinto e a instituição (DELEUZE, 2006, p. 29). Na perspectiva bergsoniana, apresentada por Deleuze (1999, p. 88ss), desde o surgimento das sociedades humanas estão implicadas compreensões inteligentes de suas necessidades e uma organização racional das atividades, mas também estão contidos, em sua formação, fatores irracionais, os quais são os elementos de conservação de sua existência enquanto sociedade. Não há sociedade sem religião, sem algum tipo de mistificação, de superstições, de representações coletivas, mais ou menos irracionais e absurdas, inscritas nas instituições, na linguagem e nos costumes. Exemplos evidentes de tais representações infundadas racionalmente são a mitologia e a tragédia grega; outro exemplo de algo arraigado tanto nas sociedades primitivas quanto nas contemporâneas que lhes dá subsistência e que está fundado em um fator irracional é a obrigação. Cada obrigação particular é convencional e pode beirar o absurdo - seja "cumprir com as obrigações morais", "sempre agir justamente", ou, simplesmente, "ter que estudar", "ter que trabalhar”, "ter que pagar dívidas”. O que há de fundado, para Bergson, é o todo da obrigação, ou seja, a obrigação de ter obrigação, a sua regularidade - nada mais que a analogia com a ordem inflexível dos fenômenos da vida - trata-se de um fundamento proveniente da natureza, imposto sobre a razão para que uma sociedade humana possa subsistir. Então, a obrigação é por nós representada como um elo entre os homens, mas também o que liga o homem individual a si mesmo. Trata-se, pois, de uma necessidade determinada pela natureza a fim de manter a coesão social (BERGSON, 2001). 
As noções de natureza e homem em Gilles Deleuze e suas relações

quer dizer, não é sempre que a solução vital criada pela natureza é um sucesso perfeito. Na linha do homem, contudo, o impulso vital passou com sucesso, ele "é a razão de ser do desenvolvimento completo" (BERGSON, 1978, p. 175; 2005, p. 200).

Este aspecto é o que Deleuze quer investigar, quer saber de onde vem o privilégio atribuído ao homem. Talvez o que pode ser o mais interessante para pensar o nosso problema. Há algo no homem que não acontece entre as demais espécies: "o homem é capaz de baralhar os planos, de ultrapassar seu próprio plano como sua própria condição, para exprimir, enfim, a Natureza naturante" (DELEUZE, 1999, p. 87; BERGSON, 1978, p. 48: "é para voltar à natura naturante que nos separamos da natura naturata"). Nesse baralhar dos planos, o homem ultrapassa o plano que de início a natureza criara para ele. $\mathrm{O}$ que não significa que o natural no homem foi expulso, pois, nas palavras de Bergson, "ele [o natural] não se deixa expulsar. Ele está sempre presente”, pois, "a natureza é indestrutível" (BERGSON, 1978, p. 226).

Valedemorar-nosum pouco mais nesteaspectoda especulação que Bergson faz e que Deleuze insiste em seu Bergsonismo. Isto porque na leitura deleuziana as possibilidades do humano se abrem, na medida em que novas faculdades, ou novos poderes - o que é o mesmo - são dados ao homem pela natureza (ou produzidas de acordo com os agenciamentos estabelecidos), para além da inteligência. Eis mais uma linha lançada para ampliar a perspectiva de nosso problema.

De início, a natureza, com sua sabedoria, ao dar ao homem a faculdade da inteligência, havia previsto uma vida em sociedade, mas numa extensão limitada: sua sociabilidade fora "calculada para culminar em pequenas sociedades, e sua inteligência destinada a favorecer a vida individual e a vida do grupo" (DELEUZE, 1999, p. 47-48). Porém, por seu próprio e imprevisível esforço, a inteligência se dilatou e assumiu um desenvolvimento inesperado. Deleuze vê, neste gesto da inteligência, a liberdade e a diferença se atualizando. Diferença que é, para Deleuze e também para Bergson, positiva e criadora.

Sobre a linha de diferenciação do homem, o impulso vital soube criar com a matéria um instrumento de liberdade, 
soube "fabricar uma mecânica que triunfava sobre o mecanismo", soube "empregar o determinismo da natureza para atravessar as malhas da rede que ele havia distendido". A liberdade tem precisamente este sentido físico: "detonar" um explosivo, utilizá-lo para movimentos cada vez mais potentes (DELEUZE, 1999, p. 87).

Neste dilatar-se da inteligência, o homem enganou a natureza, iludiu-a de muitas maneiras. Bergson apresenta dois exemplos distintos das artimanhas da inteligência. $O$ primeiro deles é referente ao que deveríamos ter em comum com os demais seres vivos: a procriação ilimitada. No entanto, com sua astúcia, a inteligência encontrou "o meio de frustrar o ato sexual de suas consequências": o homem enganou a natureza tornando-se capaz de "abster-se de colher sem renunciar ao prazer de semear" (BERGSON, 1978, p. 47). O segundo exemplo refere-se a quando o homem rompeu com o plano da natureza que previra a vida humana em pequenos grupos unidos por estreitos laços sociais, "mas que de grupo a grupo houvesse hostilidade virtual: devia-se estar sempre pronto para atacar ou defender" (Ibidem). O que fez a inteligência? Forçou as barreiras da comunidade e transformou "a solidariedade social em fraternidade humana" - o que por minha conta e risco complemento: a inteligência ilude a natureza, quebra divisas naturais e sociais, ao ponto de propor uma união planetária entre os homens.

Sabemos, no entanto, por experiência, que nenhum desses exemplos de ardil da inteligência são universalizáveis, aplicáveis a todas as inteligências existentes ${ }^{7}$. São raros os indivíduos dispostos a lançarem-se nesta aventura de uma união planetária, as hostilidades entre grupos estão por toda parte - de algum modo, as tendências orgânicas a vida em sociedade reduzida permanecem o que eram nas sociedades fechadas (BERGSON, 1978, p. 47); aliás, talvez, aqueles que tendem aos grupos fechados ainda estejam orientados pela moral elementar das sociedades primitivas; assim

7 Em O pensamento e o movente, na parte em que trata do pragmatismo de William James, Bergson afirma que a inteligência tem "hábitos de economia" (o que parece ser possível traduzir por preguiça), pois é “aficionada por simplicidade. Ela economiza o esforço e quer que a natureza se tenha arranjado de modo que só exija de nós, para ser pensada, a menor soma possível de trabalho" (BERGSON, 2006, p. 246). 
como a procriação humana que não se limita: já somos sete bilhões de humanos ocupando e devastando a Terra! É, portanto, apenas alguns indivíduos que são capazes, ao menos no princípio, de "enganar" a natureza. Para Bergson, porém, entre estes indivíduos e a natureza não se deu uma cisão, pelo contrário, o ardil dessas inteligências de gênios provém da própria natureza:

É verdade que se descêssemos até a raiz da própria natureza, talvez nos apercebêssemos de que é a mesma força que se manifesta diretamente, voltando-se sobre si mesma, na espécie humana uma vez constituída, e que atua depois indiretamente, por intermédio de individualidades privilegiadas, para impelir a humanidade para a frente (BERGSON, 1978, p. 42).

A força da natureza, contudo, não parou por aí. A fim de afirmar seu impulso vital, ao mesmo tempo em que impeliu a humanidade para frente com as potências da inteligência capazes de romperem com a sociabilidade e baralhar os planos, precisou agir contrariamente aos efeitos danosos da dilatação da inteligência. Explico: com a aparição da inteligência no homem, a vida [no homem] inventa uma série de faculdades que rompem com o instinto social, tais como a iniciativa, a independência e a liberdade. No entanto, com o uso dessas faculdades corre-se o risco de prejudicar a disciplina social, pois, uma vez enriquecida com todas elas, a vida inteligente tende a romper com os instintos gregários, e a ocupar-se, pela reflexão, com o desenvolvimento das potencialidades individuais. Surge, assim, o egoísmo - ausente nas demais espécies.

Para proteger a barreira que fora aberta pelo egoísmo e que agora ameaça a segurança do social, é preciso um guardião, uma reação ao poder dissolvente da inteligência: a natureza encontra na religião a sua primeira defesa contra a inteligência. Por meio dela, o que é habitual aos membros do grupo passa a ter um caráter religioso e, em certa medida, o elo entre os indivíduos se restabelece e o social pode ser conservado. (BERGSON, 1978, p. 101). Fica, no entanto, a questão: por quais meios a religião é produzida pela natureza?

Ainda mais. Além de oferecer perigos à sociabilidade, à vida 
de um povo e de uma cultura, a atividade da inteligência pode ser arriscada para o próprio indivíduo. Ela pode implicar um excesso de lucidez sobre o homem quando, por meio da faculdade de observar, toma consciência de que está sujeito a perigos e doenças e que irá morrer, assim, não poderá exercer o seu poder de pensar sem representar para si um futuro incerto, que lhe desperta medo. É preciso, então, uma resposta da natureza, que ponha freios à atividade da inteligência, uma vez que ela pode pôr a vida em xeque, não só pelo impulso individualista que põe em risco a coesão social, mas também porque, devido à excessiva consciência da sua finitude, da incerteza e fragilidade dos seus empreendimentos, da acumulação de conhecimentos que ultrapassam qualquer necessidade vital, produz sobre o homem certo amedrontamento e dificulta a ação do indivíduo (BERGSON, 1978, p. 134Ss).

Como resposta a tais perigos, a natureza teria desenvolvido um contraponto ao poder dissolvente e desencorajante da inteligência. Por uma necessidade vital, como uma espécie de instinto, ou melhor, um resíduo de instinto que perdura em torno da inteligência - um"instinto virtual" -, a natureza exigiu do espírito um outro gênero de atividade e criou no homem uma função compensatória, uma nova faculdade: a função fabuladora ou a faculdade de fabulação, que, sem ser um instinto, joga nas sociedades humanas um papel simétrico ao instinto nas sociedades animais (BERGSON, 1978, p. 171).

Aquela guardiã da natureza, a religião, fora criada por essa faculdade fabulatória que cumpre uma função criadora de representações fictícias, as quais, contrapostas à representação intelectual do real, tendem a equilibrar a relação de forças entre o social e o individual. Bergson indica que, em princípio, trata-se de representações religiosas, tais como os deuses da cidade, o culto aos ancestrais, crenças nos espíritos, superstições de todo gênero, as quais, por sua intensidade, levarão os indivíduos a pensar em outra coisa que não em si mesmos. Essas representações são um conjunto de ficções que constitui uma espécie de inteligência social, complementar das inteligências individuais. Tudo o que é habitual aos membros de um grupo e o que a sociedade espera dos indivíduos é alcançado pela mediação do fabuloso, através da imposição de costumes e leis religiosas. Posteriormente, a faculdade fabuladora passa a inventar, a partir da religião, a literatura e o teatro. Através 
dela, as fantasias do artista, do poeta e do dramaturgo se atualizam quando apresentam as fisionomias, as características e as histórias dos deuses (emblemático deste poder do artista é a obra de Hesíodo com sua Teogonia); quando narram suas aventuras e intervenções nos assuntos humanos (aqui, podemos pensar em Homero com suas Ilíada e Odisséia). No entanto, a fabulação, depois do período mitológico, segue tendo a mesma função enquanto uma "faculdade de alucinação voluntária" (BERGSON, 1978, p. 161).

Proteção individual e social: a função fabuladora aparece, também, como uma reação de defesa da vida individual, a própria condição da consolidação do social, uma vez que indivíduo e sociedade se implicam reciprocamente. A neutralização da hegemonia da inteligência serve de mecanismo de segurança em situações nas quais o excesso de lucidez ou de conhecimento acabaria por inundar a vida, pois, a ficção, quando é eficiente, pode ser comparada a uma alucinação nascente: ela pode contrariar o julgamento e o raciocínio, que são as faculdades propriamente intelectuais. Ora, o que fez a natureza? Apesar de ter criado seres inteligentes, a fim de frear certos perigos da atividade intelectual, mas, sem comprometer o futuro da inteligência, fez do homem também um animal imaginativo e supersticioso, não por puro prazer, mas por necessidade (BERGSON, 1978, p. 47). Com a tinta trágica nietzschiana concluímos daí que religião e arte têm uma mesma proveniência e, na sua gênese, uma única função: mascarar os terrores e atrocidades da existência, criar um antídoto para superar a negatividade da vida e dizer sim à ela.

Para Bergson (1978, p. 161), a função fabuladora, mesmo que não estivesse inicialmente presente nos planos da natureza (BERGSON, 1978, p. 163), continua cumprindo seu papel ainda hoje em nossas sociedades abertas, ainda que em diferentes graus, pode ser encontrada em todas as pessoas. Está mais viva nas crianças, por certo, mas não só; ela opera intensamente nos dramaturgos e romancistas e, por meio de suas obras, eles nos fazem sentir a existência dessa faculdade especial de alucinação voluntária, mesmo quando não somos nós os autores das ficções: é ela que entra em jogo quando nos emocionamos ao assistir um filme ${ }^{8}$,

8 Deleuze retomará o conceito de função fabuladora bergsoniano no segundo livro consagrado ao cinema (Cinema II: a imagem-tempo), pois percebe tal função viva e operante no cinema moderno e atribuirá à ela uma função política: criar um povo de falta. Para tanto, fará torções nesta noção, o que em Bergsonismo 
quando nos comovemos pelo romance que lemos e quando as mesmas sensações que atravessam as personagens passam também por nós9.

Em seus estudos em torno da filosofia de Bergson, já está inscrito o pluralismo que caracterizará toda a filosofia de Deleuze e, coerentecom ele, sua noção de homem. Apesardesofrer rearranjos ${ }^{10}$, conforme a composição de componentes e aliados que fará ao

não fora realizado.

9 Pelo recurso à faculdade fabuladora, Deleuze ainda não se dá por satisfeito frente ao problema da proveniência do privilégio do homem que se torna capaz de enganar a natureza e ultrapassar seu plano inicial de manter os homens em sociedades limitadas. Como um descobridor de segredos, Deleuze afirma que a faculdade fabuladora não teria impelido o homem a ultrapassar sua condição natural de viver em sociedades fechadas como as formigas e as abelhas, afinal, há sociedades fechadas com panteão povoado por deuses e com belas fábulas sem que ultrapassem o círculo que as isola. Segundo ele, algo que difere da inteligência e dos instintos e, ao mesmo tempo, que difere do egoismo individual inteligente e da sociabilidade quase instintiva, vem se inserir entre eles. Trata-se de um elemento puro gerador de ideias novas: a emoção criadora. Tal emoção é diversa daquelas advindas do egoísmo, da pressão social, das fantasias promovidas pela função fabuladora; essas emoções estão ligadas a representações, aquela é pura, precede a representação. Ė emoção criadora por três razões: exprime a criação em sua totalidade, funcionando "como um Deus em nós" (DELEUZE, 1999, p. 9o); porque cria a obra na qual se exprime (ainda que Bergson apresente a emoção criadora e a fabulação como aspectos presentes na criação das artes, afirmará que isso se dá em proporção variável: o romance e o teatro são criados predominantemente pela fabulação, a música, por sua vez, pela emoção e criação); a terceira razão, porque ela comunica a seus ouvintes um pouco dessa criatividade. Essa emoção criadora, Deleuze nomeará como "Memória cósmica" que libera o homem do plano da natureza, um ente adequado a todo o movimento da criação. Entretanto, não é em todo homem que essa memória cósmica se encarna, apenas em almas privilegiadas: "A emoção criadora salta de uma alma a outra, "de quando em quando", atravessando desertos fechados. Mas, a cada membro de uma sociedade fechada, se ele se abre à emoção criadora, esta comunica a ele uma espécie de reminiscência, uma agitação que lhe permite prosseguir e, de alma em alma, ela traça o desenho de uma sociedade aberta, sociedade de criadores, na qual se passa de um gênio a outro por intermédio de discípulos, de espectadores ou de ouvintes" (DELEUZE, 1999, p. 91). Com este conceito, Bergson indica a gênese da arte musical e também do misticismo, uma vez que as grandes almas são dos artistas e dos místicos, e não dos filósofos. No entanto, disso Deleuze não se ocupa, é aí que ele, "diz" a Bergson: "sim... mas...", essa emoção criadora é gênese também da intuição - o que mais interessa a Deleuze, no agenciamento com Bergson: “a intuiçãa é o método do bergsonismo [...] um dos mais elaborados métodos da filosofia” (DELEUZE, 1999, p. 7), mas esse já é outro problema que não nos diz respeito neste momento...

10 Um filósofo não para de remanejar seus conceitos, e mesmo de mudá-los; basta às vezes um ponto de detalhe que se avoluma, e produz uma nova condensação, acrescenta ou retira componentes. O filósofo apresenta às vezes uma amnésia que faz dele quase um doente: Nietzsche, diz Jaspers, "corrigia ele mesmo suas ideias, para constituir novas, sem confessá-lo explicitamente; em seus estados de alteração, esquecia as conclusões as quais tinha chegado anteriormente”. Ou Leibniz: "eu acreditava entrar no porto, mas... fui jogado novamente em pleno mar" (DELEUZE e GUATTARI, 1992, p. 34). 
As noções de natureza e homem em Gilles Deleuze e suas relações

longo das demais obras, Deleuze nunca definirá o homem por uma única faculdade: a inteligência, ou a razão, ou o pensamento. Ao contrário, o homem é a composição de um conjunto de faculdades não necessariamente convergentes.

A terceira figura fecha a tríade dos intercessores de Deleuze, provindos da história da filosofia, que contribuíram definitivamente para a criação de uma filosofia vitalista e, a seu modo, pode funcionar ao lado de Spinoza e Bergson naquilo que nos interessa aqui: as noções de natureza, homem e suas relações. Trata-se de Nietzsche, aquele que, para Deleuze (DELEUZE, 1992, p. 15), é o filósofo que "dá o gosto para cada um de dizer coisas simples em nome próprio, de falar por afectos, intensidades, experiências e experimentações”. O prefácio do livro que Nietzsche nunca escreveu, $A$ disputa de Homero, inicia com a peremptória recusa da separação entre natureza e homem, em suas palavras:

Quando se fala de humanidade, a noção fundamental é a de algo que separa e distingue o homem da natureza. Mas uma tal separação não existe na realidade: as qualidades "naturais" e as propriamente chamadas "humanas" cresceram conjuntamente. O ser humano, em suas mais elevadas e nobres capacidades, é totalmente natureza... (NIETZSCHE, 1996, p. 73).

Para compreender a tematização da cultura, do mundo inventado pelo homem, feita por Nietzsche, a qual Deleuze corrobora, é, portanto, imprescindível não fazer oposição entre natureza e cultura, uma vez que ele considera que a separação entre natureza e homem não existe. Tal divisão trata-se de uma mistificação metafísica, pois em suas faculdades mais nobres e elevadas, o homem é inteiramente natureza e carrega em si a estranheza deste duplo caráter natural. Ao tematizar sobre a cultura, Nietzsche quer cumprir a tarefa de triunfar sobre as interpretações que separaram o homem da natureza, que romperam com o texto homo natura e retraduzir o homem de volta à natureza, ele quer:

Fazer com que no futuro o homem se coloque frente ao homem tal como hoje, endurecido na disciplina da ciência já se coloca frente à outra natureza, com intrépidos olhos 
de Édipo e ouvidos tapados como os de Ulisses, surdo às melodias dos velhos, metafísicos apanhadores de pássaros, que por muito tempo lhe sussurraram: "Você é mais! É superior! Tem outra origem!” (NIETZSCHE, 1992, § 230).

Na medida em que Nietzsche interpreta as coisas humanas e a natureza num mesmo plano, o princípio irredutível da cultura é o mesmo de tudo o que vive: os instintos, as forças - exatamenteaquilo que é tomado como inumano por aqueles que querem dar uma origem superior ao homem. Seguindo esse princípio, a perspectiva deleuziana interpreta que a cultura exprime a violência das forças que se apoderam do pensamento, pondo em jogo o inconsciente do pensador, porque é nele que a atividade do nosso espírito ocorre, onde a espécie mais vigorosa de pensamento acontece. Deleuze encontrou em Nietzsche uma nova aproximação da ideia de um empirismo superior: fez da teoria da vontade de potência o novo princípio de compreensão das condições de efetividade da experiência; definiu-a como força plástica interna das forças e das representações; pelo conceito de vontade de potência criou um método genealógico que permitiu Deleuze determinar a gênese ativa e reativa das faculdades e de seus usos.

Esse momento da obra de Deleuze será apresentado pelas jovens pesquisadoras nos encontros de estudos restritos ao PET, por essa razão, não apresentarei essa leitura de Deleuze. Ao invés disso, aproveitarei a oportunidade para finalizar a apresentação e mostrar que Deleuze, especialmente quando está com Guattari, pensa a constituição do mundo, da cultura em relação com o animal, assim como a tarefa do escritor como aquele que está à espreita, tal como um animal. Não que ele ignore as diferenças entre os animais e os homens, mas, coerente com um pensamento pluralista, que comporta uma multiplicidade de perspectivas coletivas sobre a vida, pensa a produção de subjetividades e a constituição de mundo a partir de possíveis agenciamentos também com moléculas inumanas. Aliás, toda sua perspectiva ética, ele afirmará, se trata de uma etologia, a ciência que estuda as composições de relações ou de poderes entre as coisas. Sua ética será, então, "uma sinfonia da Natureza, da constituição de um mundo cada vez mais amplo e intenso" (DELEUZE, 2002, p. 133). Para a constituição de um mundo, trata-se, portanto, de criar agenciamentos compostos de elementos 
As noções de natureza e homem em Gilles Deleuze e suas relações

humanos e também inumanos, como forças animais, vegetais, minerais, mecânicas. Nesta composição ainda haverá homem? Deleuze aposta e indica que, na medida em que o homem entra em relação com novas forças é uma nova forma que se constitui. Será isso, ainda, o homem? Talvez, nos aproximemos mais do além-dohomem. Aliás, na medida em que há muito entramos em relação com o silício - e vocês, jovens mais do que nós, os velhos - seremos ainda homens?

\section{Referências bibliográficas}

BERGSON, Henri. As duas fontes da moral e da religião. São Paulo: Zahar, 1978.

. O pensamento e o movente: ensaios e conferências.

Tradução de Bento Prado Neto. São Paulo: Martins Fontes, 2006.

DELEUZE, Gilles; GUATTARI, Félix. O que é a Filosofia? São Paulo: Ed.34, 1992.

DELEUZE, Gilles. Diferença e repetição. Tradução de Luiz Orlandi e Roberto Machado. Rio de Janeiro: Graal, 1988.

. Conversações, 1972 - 1990. Tradução de Peter Pál Pelbart. Rio de Janeiro: 34, 1992.

. Hume. In. CHÂTELET, François. História da filosofia.

(vol.2). Lisboa: Dom Quixote, 1995, p. 209-219.

. Crítica e clínica. Tradução de Peter Pál Pelbart. São Paulo: 34, 1997.

. Bergsonismo. Tradução de Luiz B. L. Orlandi. São Paulo: 34, 1999a.

. O abecedário de Gilles Deleuze. Vídeo. Editado no Brasil pelo Ministério de Educação, “TV Escola”, $2001 a$. 
. Empirismo e subjetividade: ensaio sobre a natureza humana segundo Hume. Tradução de Luiz Orlandi. São Paulo: 34, 2001b.

. Espinosa: filosofia prática. Tradução de Daniel Lins e Fabien Lins. São Paulo: Escuta, 2002.

. Imanência: uma vida; tradução de Tomaz Tadeu. In. Revista Educação E Realidade - v. 27, $\mathrm{n}^{\circ} 2$ (jul/dez). Porto Alegre: Universidade Federal do Rio Grande do Sul, 2002, p. 10-17.

A ilha deserta: e outros textos; edição preparada por David Lapoujade; organização da edição brasileira e revisão técnica Luiz B. L. Orlandi. São Paulo: Iluminuras, 2006.

DOSSE, François. Biografias cruzadas: Gilles Deleuze \& Félix Guattari. Porto Alegre: ARTMED, 2010.

HEUSER, Ester Maria Dreher. Pensar em Deleuze: violência e empirismo no ensino de filosofia. Ijuí: UNIJUÍ, 2010.

HUME, David. Tratado da natureza humana: uma tentativa de introduzir o método experimental de raciocínio nos assuntos morais. São Paulo: UNESP, 2001.

NIETZSCHE, Friedrich. Além do bem e do mal: prelúdio a uma filosofia do futuro. Tradução de Paulo César de Souza. São Paulo: Companhia das Letras, 1992.

. Cinco prefácios para cinco livros não escritos. Tradução de Pedro Süssekind. Rio de Janeiro: 7 Letras, 1996.

SPINOZA, Benedictus de. Ética. Tradução de Tomaz Tadeu. Belo Horizonte: Autêntica, 2007. 